\section{Impact of the Haemophilus influenzae type $b$ vaccination program on HIB meningitis in Brazil}

\author{
Impacto do programa de vacinação contra \\ meningites causadas por Haemophilus influenzae \\ tipo b no Brasil
}

Sybelle de Souza Castro Miranzi 1

Suzana Alves de Moraes 2

Isabel Cristina Martins de Freitas 2

\footnotetext{
${ }^{1}$ Departamento de Medicina Social, Universidade Federal do Triângulo Mineiro, Uberaba, Brasil. 2 Escola de Enfermagem de Ribeirão Preto, Universidade de São Paulo, Ribeirão Preto, Brasil.

Correspondence S. A. Moraes

Núcleo de Epidemiologia, Escola de Enfermagem de Ribeirão Preto, Universidade de São Paulo. Av. dos Bandeirantes 3900 Ribeirão Preto, SP 14040-902, Brazil. samoraes@usp.br
}

\section{Abstract}

This study aimed to evaluate the impact of vaccination against Haemophilus influenzae type $b$ (HIB) in Brazil on the morbidity, mortality, and case fatality of HIB meningitis, using the Ministry of Health database and population data from the Brazilian Institute of Geography and Statistics (Instituto Brasileiro de Geografia e Estatística-IBGE). Impact was evaluated through a time series analysis (1983-2002), using regression forecasting $(R F)$ by dividing the time series into two periods: (a) historical (1983-1998) and (b) validation (1999-2002). Impact of the vaccination was positive, although more significant for incidence and mortality than for case fatality rates.

Haemophilus influenzae; Bacterial Meningitis; Vaccination; Time Series Studies

\section{Introduction}

Meningitis caused by Haemophilus influenzae type b (HIB) represents an important health problem in Brazil, due both to its clinical-epidemiological characteristics and its heavy socioeconomic impact.

As a result of the meningococcal meningitis epidemic (1972-1976), the Brazilian Ministry of Health implemented the meningitis epidemiological surveillance program, with special attention to several etiologies, including meningitis caused by Haemophilus bacilli 1 .

In addition to respiratory infections, HIB can cause serious invasive disease, including meningitis, pneumonia, epiglottitis, sinusitis, bacteremia, otitis, and arthritis 2,3,4. Within this group, bacterial meningitis has received the most attention due to its high morbidity and mortality rates and the specific laboratory diagnosis for clinical cases, as well as its compulsory notification.

Haemophilus influenzae type b meningitis is an endemic disease in Brazil, predominating in infants $(<1$ year of age) $1,5,6$. The conjugate vaccine with diphtheria $\mathrm{CRM}_{197}$ protein was introduced in the routine schedule of the National Immunization Program (NIP) in August 1999. Considering the recent introduction of HIB vaccination in the NIP routine and data availability for time series studies, the current research aimed to evaluate the impact of HIB vaccination on a historical time series from 1983 to 2002. 


\section{Methods}

The ecological design used a historical time series from 1983 to 2002, calculating the incidence, mortality (expressed per 100,000), and case fatality (\%) rates due to HIB and other unspecified bacterial meningitis in the under-5-year age group, based on databases from the Ministry of Health (cases and confirmed deaths) and the Brazilian Institute of Geography and Statistics (Instituto Brasileiro de Geografia e Estatística - IBGE) (population data). The impact of vaccination was evaluated by regression forecasting (RF) proposed by Box et al. 7 using models with the "incidence", "mortality", and "case fatality" rates (y axis) and time series ( $\mathrm{x}$ axis). The time series was divided into two periods: (1) "historical" (1983-1998) and (2) "validation” (1999-2002). The models only considered the historical period (before vaccination was introduced), enabling calculation of the straightline prediction for the period and forecasting the indicators for the validation period (after introduction of the vaccine). Point estimates and confidence intervals $(95 \% \mathrm{CI})$ were calculated. The study used the Stata software, version 7.0 (Stata Corp., College Station, USA). Incidence and mortality rates and the number of observed, expected, and prevented cases and deaths due to HIB and unspecified bacterial meningitis were calculated for two periods: before (1983-1998) and after vaccination (1999-2002).

\section{Results}

Figure 1 shows straight-line predictions and forecasts for the incidence, mortality, and case fatality rates and the respective confidence intervals in the under-5 age group. As expected, there was a greater impact of HIB vaccination on HIB meningitis than on unspecified bacterial meningitis.

Incidence and mortality rates showed an upward trend until 1998, which was expected to continue if the vaccination had not been introduced (Figure 1). However, after vaccination was introduced into the routine immunization schedule, the significant decrease in incidence and mortality rates indicates the vaccine's positive impact from 1999 onwards. Haemophilus influenzae type b vaccination also had an effect on unspecified bacterial meningitis rates, but not as evident as for HIB meningitis.

Although HIB case fatality rates had been decreasing since the beginning of the series, they remained high until 2001, so that the impact of vaccination was most evident in 2002. Related to unspecified bacterial meningitis, the HIB vaccine had no effect on case fatality.
Table 1 shows HIB vaccine coverage in Brazil from 1999 to 2002, with levels $\geq 90 \%$ after its introduction. Table 2 shows a decrease of $52 \%$ in the number of expected HIB cases (2,363 prevented cases) and $63 \%$ in the number of expected deaths (525 prevented deaths) since introduction of the vaccine. Related to unspecified bacterial meningitis, the number of expected cases increased by $42 \%$ and the number of expected deaths fell by $6 \%$.

Table 1

Vaccine coverage (\%) against meningitis due to Haemophilus influenzae type $b$ in children less than 1 year of age, according to calendar year. Brazil, 1999-2002.

\begin{tabular}{lc}
\hline Year & Vaccine coverage (\%) \\
\hline 1999 & 5.09 \\
2000 & 99.80 \\
2001 & 92.28 \\
2002 & 90.00
\end{tabular}

Source: Data and Information Technology Department, Unified National Health System (Departamento de Informação e Informática do SUS - DATASUS) 32.

\section{Discussion}

Due to the lack of epidemiological studies on invasive diseases caused by HIB, the inclusion of this vaccine in immunization programs in developing countries was based on information from international studies that identified these diseases as one of the world's most serious public health problems 5,8 , as well as on the efficacy of the conjugate HIB vaccine 9,10,11.

After conjugate HIB vaccines were included in routine immunization programs in the 1990s, diseases caused by HIB practically disappeared from Western Europe, Canada, United States, Australia, and New Zealand 12. Conjugate vaccines also demonstrated their effectiveness in preventing invasive diseases caused by HIB in developing countries 13,14. Although this study was not designed to evaluate the vaccine's efficacy, the results support the conclusion that the vaccine had a positive impact on HIB meningitis in Brazil.

Furthermore, prospects for drug treatment of HIB infections are limited by the development of antimicrobial resistance 15,16 and the fact that HIB chemoprophylaxis is not very effective. In this sense, vaccination is important for control- 
Incidence, mortality and case-fatality trends related to Haemophilus influenzae type b meningitis (A) and unspecified bacterial meningitis (B) in children under 5 years old. Brazil, 1983 to 2002

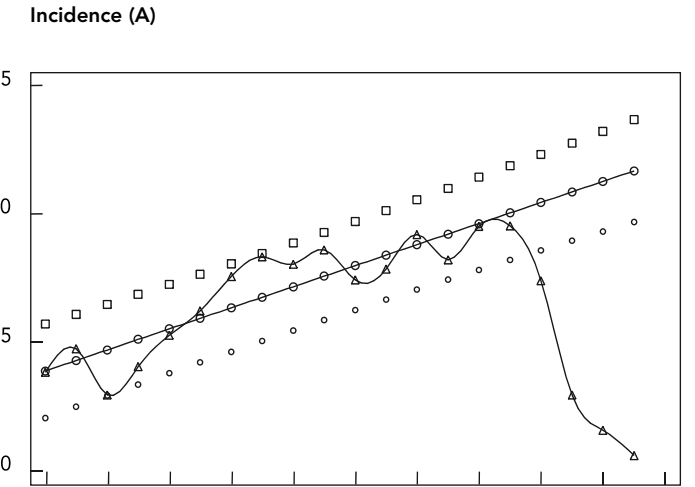

$198319851987198919911993 \quad 19951997 \quad 199920012003$ Calendar years

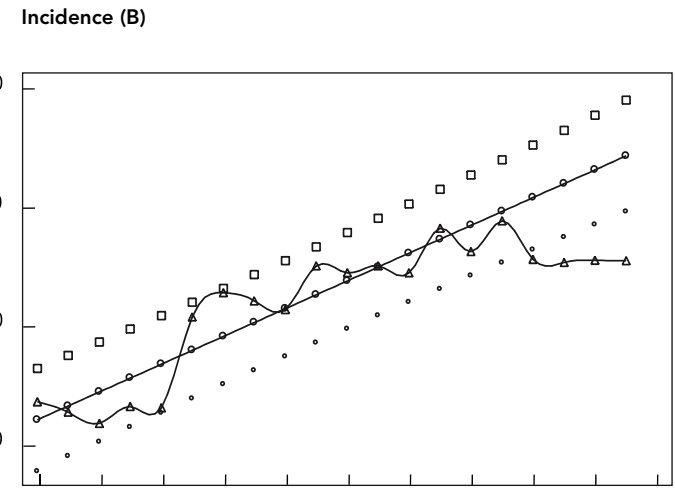

$\begin{array}{llllllllllll}1983 & 1985 & 1987 & 1989 & 1991 & 1993 & 1995 & 1997 & 1999 & 2001 & 2003 & \text { Calendar }\end{array}$

years

\section{Mortality (A)}

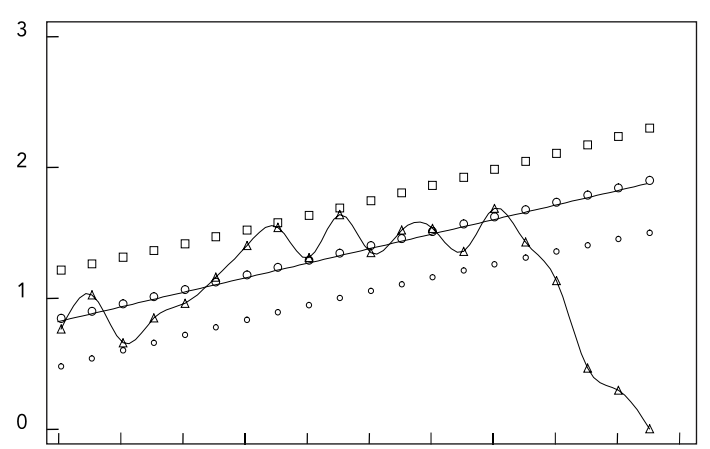

$19831985198719891991199319951997 \quad 199920012003$ Calendar years
Mortality (B)

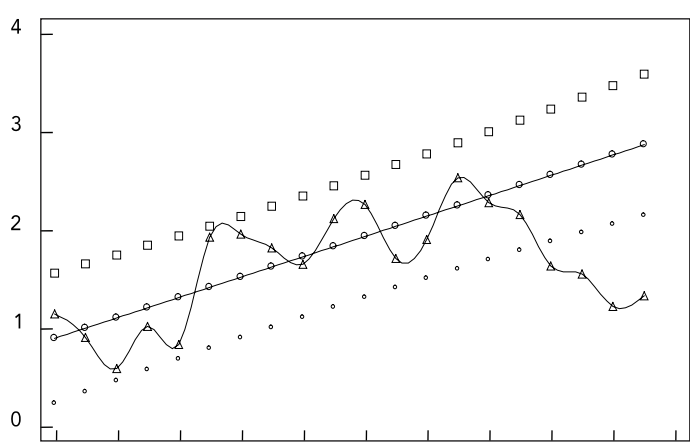

$\begin{array}{llllllllllll}1983 & 1985 & 1987 & 1989 & 1991 & 1993 & 1995 & 1997 & 1999 & 2001 & 2003 & \text { Calendar }\end{array}$

years

\section{Case-Fatality (A)}

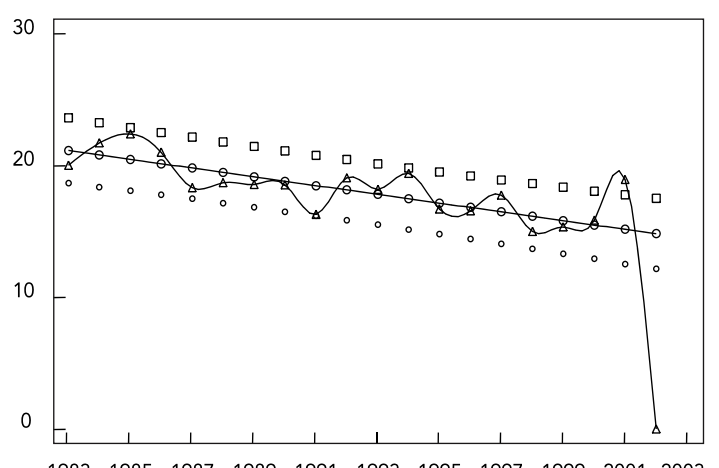

199920012003
Case-Fatality (B)

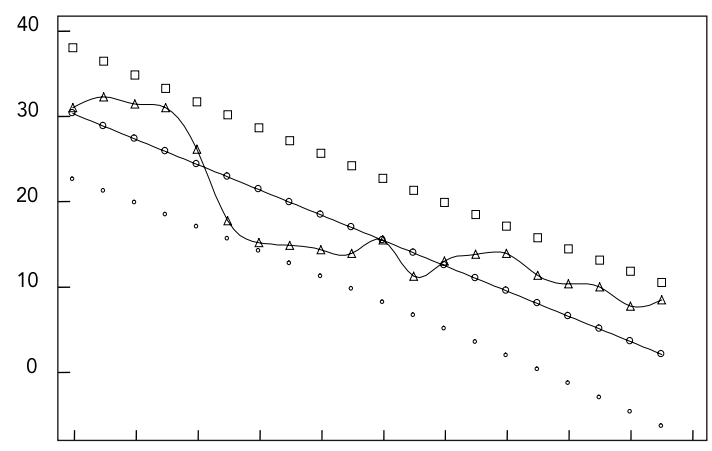

$\begin{array}{lllllllllll}1983 & 1985 & 1987 & 1989 & 1991 & 1993 & 1995 & 1997 & 1999 & 2001 & 2003 \\ \text { Calendar }\end{array}$ 
Incidence and mortality rates * and prevented cases and deaths ** from Haemophilus influenzae type b or unspecified bacterial meningitis in children less than 5 years of age. Brazil, 1983-2002.

\begin{tabular}{|c|c|c|c|c|}
\hline & \multicolumn{2}{|c|}{ Haemophilus influenzae } & \multicolumn{2}{|c|}{ Unspecified bacterial meningitis } \\
\hline & Pre-vaccine & Post-vaccine & Pre-vaccine & Post-vaccine \\
\hline Observed cases & 17,994 & 2,159 & 28,765 & 10,296 \\
\hline Incidence rate & 6.83 & 3.26 & 10.92 & 15.55 \\
\hline Expected cases $\star \star \star ~$ & - & 4,522 & - & 7,229 \\
\hline Prevented/Excess cases & - & $-2,363$ & - & $+3,067$ \\
\hline Observed deaths & 3,323 & 310 & 4,407 & 948 \\
\hline Mortality rate & 1.26 & 0.47 & 1.67 & 1.43 \\
\hline Expected deaths \# & - & 835 & - & 1,107 \\
\hline Prevented/Excess deaths & - & -525 & - & -159 \\
\hline
\end{tabular}

* Incidence and mortality rates (x 10-5) in the pre- and post-vaccination periods;

** Prevented/Excess cases and deaths in the post-vaccination period ( $N$ observed $-\mathrm{N}$ expected);

$\star \star \star$ Incidence rate in the pre-vaccination period $x$ population in the post-vaccination period;

\# Mortality rate in the pre-vaccination period $x$ population in the post-vaccination period.

ling invasive diseases caused by HIB, particularly considering that HIB is the second most frequent cause of bacterial meningitis in Brazil.

Within the group of invasive HIB diseases, meningitis is prone to possible epidemiological control by surveillance actions including case notification and hospitalization.

The meningitis surveillance system is an important source of epidemiological information, identifying the population at risk of acquiring the disease, the specific nature of pathogenic agents, and the causal pathway needed to plan appropriate public health measures. However, besides improving the notification system, data quality must be assured in order to identify the best prevention strategies.

From 1983 to $2002,379,352$ cases of meningitis were reported in Brazil, including 24,710 (6.51\%) cases of HIB meningitis $(81.6 \%$ in children under 5). The predominance of HIB meningitis in this age group, also reported in other studies 17,18,19, can result from the low immune capacity of under-fives to produce anti-PRP (polyribosylribitol phosphate) antibodies. In other regions where the vaccine has not been introduced, protection against HIB can be stimulated by sub-clinical infections with serotype $b$ or the presence of antigens similar to PRP, which are found in some bacterial species, especially enterobacteria 20 .

The magnitude of the incidence, mortality, and case fatality rates in this study might be even higher if the following factors are taken into account: (1) cases submitted to microbiological investigation and laboratory cultures to identify
HIB are not always free from previous exposure to antibiotics; (2) some cases may not be included in the surveillance system; and (3) in general, physicians diagnosing cases at private services do not complete the systematic notification forms.

The present study showed an increase in incidence and mortality rates from 1988 onwards, which could be related to improved health surveillance actions at the local, State, and Federal levels, by means of policies that encouraged notification of the diseases 21 . The results may also be related to progressive improvement in diagnostic quality in Brazil, as since 1989, when cases began to be identified according to etiological agent 1 .

After 1999, the declining incidence and mortality rates showed that vaccination had the expected impact on the disease. The sharp decrease in these rates for HIB meningitis corroborates the conjugate vaccine's effectiveness in Brazil. However, the expansion of vaccine coverage and monitoring of HIB invasive diseases should be encouraged in the country in order to prevent cases and deaths and to evaluate the need for a booster dose 22 . The declining rates for unspecified bacterial meningitis appear to result from improved diagnostic quality, and it is reasonable to suppose that a residual number of HIB meningitis cases in that group may also have been prevented by the specific vaccination. Since case fatality rates were already decreasing even before the vaccine was introduced, the vaccine apparently did not affect this indicator as much as it did incidence and mortality rates during the initial years of vaccination. 
According to Heath et al. 23, even after largescale vaccination, some cases of invasive disease can occur. Clinical and immunological risk factors related to the occurrence of cases include prematurity; age less than one year; Down syndrome; and childhood cancer, which can contribute to immunodeficiency. However, other factors must be taken into account when new cases appear, such as deficient product storage or errors in administering the vaccine. According to the literature, the small number of new cases in regions where the HIB vaccine has been introduced have occurred in individuals with an incomplete vaccination schedule, age groups that did not receive the vaccine, or non-immunized persons 24,25,26,27. Therefore, efforts to control invasive HIB disease continue to be encouraged by creating collective awareness about the disease's severity, effective surveillance programs, and expansion of vaccine coverage 25,28 .

In evaluating the impact of the HIB vaccination program in children less than 5 years of age worldwide, several authors have presented similar results on the decrease in incidence levels, using time intervals in the pre- and postvaccination periods that were similar to those in the present study 3,24,29,30,31. In Brazil, no studies have been published with large time series to evaluate the incidence and mortality rates in the pre-vaccination period. However, the present study's findings on the trend in incidence rates are similar to those reported by Simões et al. 22 .

Studies with an ecological design (secondary databases) have a number of limitations. Meanwhile, the availability of data through systematic collection appears to be useful for comparative studies between observed and forecasted values as a strategy to evaluate the impact of vaccination on different epidemiological indicators.

In short, the improvement of quality control for HIB meningitis notification and vaccine coverage, along with the results provided by new studies in Brazil, may finally optimize strategies for planning, managing, and evaluating health promotion and prevention programs.

\section{Resumo}

A proposta deste trabalho foi avaliar o impacto da vacinação contra Haemophilus influenzae tipo b (HIB) no Brasil sobre a morbi-mortalidade e a letalidade das meningites por HIB, a partir de base de dados fornecida pelo Ministério da Saúde e as estimativas populacionais provenientes do Instituto Brasileiro de Geografia e Estatística (IBGE). Para a avaliação do impacto utilizou-se análise de tendência temporal (1983-2002), aplicando-se a técnica $R F$ (regression forecasting), dividindo-se a série em dois períodos: (a) período histórico (1983-1998) e (b) período de estimação (1999-2002). O impacto da vacinação foi positivo, embora tenha se revelado mais expressivo sobre a morbi-mortalidade que sobre a letalidade.

Haemophilus influenzae; Meningite Bacteriana; Vacinação; Estudos de Séries Temporais

\section{Contributors}

All the authors participated in drafting the article and in all its contents, including data analysis.

\section{Acknowledgements}

The authors wish to thank the Brazilian National Research Council (Conselho Nacional de Desenvolvimento Científico e Tecnológico - CNPq) for the PhD grant provided to S. S. C. Miranzi. 


\section{References}

1. Freitas HSA, Oliveira RA, Souza BCM. Meningite por Haemophilus: Brasil - 1987/1991. Inf Epidemiol SUS 1993; 2:35-56.

2. Clements DA, Booy R, Dagan R. Comparison of the epidemiology and cost of Haemophilus influenzae type $b$ disease in five western countries. Pediatr Infect Dis J 1993; 12:362-7.

3. Levine OS, Schwartz B, Pierce N, Kane M. Development, evaluation and implementation of Haemophilus influenzae type b vaccines for young children in developing countries: current status and priority actions. Pediatr Infect Dis J 1998; 17:95-113.

4. Ward JI, Zangwill KM. Haemophilus influenzae vaccines. In: Plotkin WA, editor. Vaccines. Philadelphia: Saunders Company; 1999. p. 183-221.

5. Ministério da Saúde. Informe técnico para a implantação da vacina contra o Haemophilus influenzae tipo b. Brasília: Centro Nacional de Epidemiologia, Ministério da Saúde; 1999.

6. Miranzi SSC, Camacho LAB, Valente JG. Haemophilus influenzae tipo b: situação epidemiológica no Estado de Minas Gerais, Brasil, 1993 a 1997. Cad Saúde Pública 2003; 19:1267-75.

7. Box GEP, Jenkins JM, Reinsel GC. Time series analysis: forecasting and control. 3rd Ed. Englewood Cliffs: Prentice- Hall; 1994.

8. World Health Organization. Generic protocol for population-based surveillance of Haemophilus influenzae type b. Atlanta: Centers for Disease Control and Prevention/Geneva: World Health Organization; 1996.

9. Booy R, Hodgson S, Carpenter L, Mayon-White RT, Slack MP, Macfarlane JA, et al. Efficacy of Haemophilus influenzae type $\mathrm{b}$ conjugate vaccine PRP-T. Lancet 1994; 344:362-6.

10. Decker MD, Edwards K. Haemophilus influenzae type $\mathrm{b}$ vaccines: history, choice and comparisons. Pediatr Infect Dis J 1998; 17:113-6.

11. Heath PT. Haemophilus influenzae type b conjugate vaccines: a review of efficacy data. Pediatr Infect Dis J 1998; 17:117-22.

12. World Health Organization. Global program for vaccines and immunization (GPV). Wkly Epidemiol Rec 1998; 73:64-71.

13. Lagos R, Horwitz J, Toro J, San Martin O, Abrego P, Bustamante C, et al. Large scale, post licensure, selective vaccination of Chilean infants with PRP-T conjugate vaccine: practicality and effectiveness in preventing invasive Haemophilus influenzae type b infections. Pediatr Infect Dis J 1996; 15:216-22.

14. Mulhollad EK, Helton S, Adegbola RA, Usen S, Oparaugo A, Omosigho C, et al. Randomized trial of Haemophilus influenzae type b tetanus protein conjugate for prevention of pneumonia and meningitis in Gambian infants. Lancet 1997; 349: 1191-7.

15. Casagrande ST, Vicente EJ, Landgraf IM, Kobata AMM. Antimicrobial resistance patterns of Haemophilus influenzae isolated from patients with meningitis in São Paulo, Brazil. Braz J Med Biol Res 2000; 33:295-300.
16. Zanella RC, Casagrande ST, Bokermann S, Almeida SCG, Brandileone MCC. Characterization of Haemophilus influenzae isolated from invasive disease in Brazil from 1990 to 1999. Microb Drug Resist 2002; 8:67-72.

17. Barton-Forbes MA, Samms-Vaughan M, Irons B. Epidemiology of Haemophilus influenzae invasive disease in Jamaica, 1990-1993. West Indian Med J 2000; 49:200-4.

18. Kamiya H, Uerara S, Kato T, Shiraki K, Togashi $\mathrm{T}$, Morishima T, et al. Childhood bacterial meningitis in Japan. Pediatr Infect Dis J 1998; 17:183-5.

19. Ferraz IQ, Figueiredo AVA, Martins RP, Scala RS, Moreira TCR, Silva TE. Ocorrência de meningites por Neisseria meningitidis, Haemophilus influenzae e Streptococcus pneumoniae no Distrito Federal, no período de 1989 a 1995. Rev Saúde Dist Fed 1996; 7:19-24.

20. Toledo MRF. Haemophilus. In: Trabulsi LR, organizador. Microbiologia. Rio de Janeiro/São Paulo: Editora Atheneu; 1991. p. 133-40.

21. Ministério da Saúde. Norma operacional básica - NOB 001/96. Brasília: Ministério da Saúde; 1996.

22. Simões LLP, Andrade ALSS, Laval CA, Oliveira RM, Silva AS, Martelli CMT, et al. Impacto da vacinação contra Haemophilus influenzae tipo b na redução das meningites, Goiás. Rev Saúde Pública 2004; 38:664-70.

23. Heath PT, Booy R, Griffiths H, Buck E, Azzopardi HI, Slack MPE, et al. Clinical and immunological risk factors associated with Haemophilus influenzae type b conjugate vaccine failure in childhood. Clin Infect Dis 2000; 31:973-80.

24. Ruocco G, Curto S, Sávio M, Laurani H, Frocht R. Vacunación contra Haemophilus influenzae tipo b en el Uruguay: experiencia e impacto. Rev Panam Salud Pública 1999; 5:197-9.

25. Fry AM, Lurie, P, Gidley M, Schmink S, Lingappa $\mathrm{J}$, Fischer M, et al. Haemophilus influenzae type b disease among Amish children in Pennsylvania: reasons for persistent disease. Pediatrics 2001; 108: E60.

26. Peltola H. Worldwide Haemophilus influenzae type $b$ disease at the beginning of the 21 st century: global analysis of the disease burden 25 years after the use of the polysaccharide vaccine and a decade after the advent of conjugates. Clin Microbiol Rev 2000; 13:302-17.

27. Jafari HS, Adams WQ, Robinson KA, Plikaytis BD, Wenger JD. Efficacy of Haemophilus influenzae type $\mathrm{b}$ conjugate vaccines and persistence of disease in disadvantaged populations. Am J Public Health 1999; 89:364-8.

28. Santosham M. Can Haemophilus influenzae type b disease be eliminated from the United States? J Pediatr 2000; 137:295-8.

29. Zhou F, Bisgard KM, Yusuf HR, Deuson RR, Bath SK, Murphy TV. Impact of universal Haemophilus influenzae type b vaccination starting at 2 months of age in the United States: an economic analysis. Pediatrics 2002; 110:653-61. 
30. Slack MPEF, Azzopardi HJ, Hargreaves RM, Ramsay ME. Enhanced surveillance of invasive Haemophilus influenzae disease in England, 1990 to 1996: impact of conjugate vaccines. Pediatr Infect Dis J 1998; 17(9 Suppl):S204-7.
31. Gallo G, Atti MLCD, Cerquetti M, Piovesan C, Tozzi $\mathrm{AE}$, Salmaso S. Impact of a regional vaccination programme in Italy. Vaccine 2002; 20:993-5.

32. Departamento de Informação e Informática do SUS. Informações estatísticas - coberturas. http:// pni.datasus.gov.br/inf_estatistica_cobertura.asp (accessed on 09/May/2004).

Submitted on $22 /$ Jun/2005

Final version resubmitted on 30/Oct/2006

Approved on 27/Dec/2006 